\title{
Was the 4.2 ka Event an Anthropogenic Disaster?
}

\author{
Tomasz Jarosław Szczęsny \\ Faculty of Political Science and International Studies, Nicolaus Copernicus University in Toruń, Toruń, Poland \\ Email: tomjaszczesny@gmail.com
}

How to cite this paper: Szczęsny, T.J. (2016) Was the 4.2 ka Event an Anthropogenic Disaster? Open Journal of Ecology, 6, 613-631.

http://dx.doi.org/10.4236/oje.2016.610058

Received: July 27, 2016

Accepted: September 24, 2016

Published: September 27, 2016

Copyright $\odot 2016$ by author and Scientific Research Publishing Inc. This work is licensed under the Creative Commons Attribution International License (CC BY 4.0).

http://creativecommons.org/licenses/by/4.0/

\begin{abstract}
The article describes a possible impact of demographic explosion during the Neolith on local ecosystems and on the global climate as well as the role of this explosion in aggravating the course of $4.2 \mathrm{ka}$ cooling event. A possible role of human activity in changing the pattern of mid-latitudes westerlies, monsoons and Walker circulation throughout the Holocene is analyzed. It is explained why during the Holocene Climatic Optimum (HCO) monsoons could have been weaker than today, not stronger, as it is commonly stated. It is described how during the HCO the humid Tibetan Plateau could have repelled the Indian monsoon to the west and the East Asian monsoon to the north. The explanation for weaker El Niño-Southern Oscillation (ENSO) during $\mathrm{HCO}$ is proposed.
\end{abstract}

\section{Keywords}

Holocene Climatic Optimum, Walker Circulation, Monsoon, Green Sahara Period, 4.2 ka Event

\section{Introduction}

The growing evidence of global warming which is observed in recent decades probably caused by an increase in greenhouse gas concentrations in the atmosphere, particularly carbon dioxide and chlorofluorocarbons, prompts scientists to research climate changes which occur during the Holocene, i.e. after the end of the last ice age. It is believed that understanding the mechanisms of climate changes which occur in this period allows to predict future climate changes because the shape of lands and seas throughout the Holocene is similar.

An analysis of the composition of marine and lacustrine sediments, stalactites, stalagmites, deep layers of the glaciers as well as coral reefs and dendrology data, allows with an accuracy of up to one century to calculate the amount of precipitation (P), evaporation (E), the P/E ratio, sea surface temperature (SST) as well as to determine the 
type of vegetation and prevailing wind direction. This information is also supplemented with archaeological data: based on cave paintings made by the Neolithic people, conjectures can be made about the type of fauna [1]-[3] and from the excavations one can make an intelligent guess about the size and degree of organization of human settlements. The so-called Neolithic Revolution, the biggest success of which was the domestication of animals and the development of agriculture has led to a demographic explosion, emergence of specialized occupations, the first societies, cities and states. An abrupt end of this "golden period" of the Neolith around 4200 years ago was concomitant with lasting almost two centuries period of drought and cold (4.2 ka event) [4]-[7]. Evidence for rapid cooling and desertification is found especially along the Tropic of Cancer. It was accompanied by the collapse of many Neolithic civilizations: oases in the Sahara, the Old Kingdom in Egypt, the Akkadian Empire in Mesopotamia, the Indus Valley Civilization and a number of civilizations in northern China and Inner Mongolia. During the $4.2 \mathrm{ka}$ event, cooling and desertification concentrated predominantly around the Tropic of Cancer and were more intense then than during other similar periods occurring approximately every 1500 years, called Bond cycles, whose existence is usually explained by changes of solar activity [8] or oceanic circulation [9]. Unlike an earlier great global climate cooling, called the Late Glacial or Younger Dryas, which took place about 12,800 - 11,700 years ago (probably caused by the overflow of fresh water from melted North American glaciers through the St. Lawrence River [10] and freshwater Baltic Ice Lake [11] to the North Atlantic which hampered the thermohaline circulation of the Gulf Stream), the $4.2 \mathrm{ka}$ event was not accompanied with a reduced precipitation in the northern mid-latitudes [12]. The $4.2 \mathrm{ka}$ desertification and cooling predominantly affected places which on all continents of the northern hemisphere were the cradles of civilization. For this reason, the question arises whether there may be a relationship between the demographic explosion in the Neolith and remarkably abrupt climate change and whether the human activity could have influenced the intensity of Bond event 3. If so, it could be regarded as the first anthropogenic global ecological disaster.

\section{The Holocene Climatic Optimum (HCO)}

During the last million years, at pace of 40,000 - 100,000 years, glaciations occurred on Earth. The reason of timing of ice ages is still not clear but they correlate well with precession of the Earth's orbit. After the end of the last ice age a period of warming called Bølling/Allerød took place, which lasted about 2000 years, and was followed by a cool period known as Younger Dryas. Further global warming resulted in melting of the remnants of the Scandinavian and Laurentide Ice Sheets. Within the cycle of the precession of the Earth's axis, lasting about 26,000 years, called Platonic year, it coincided with the greatest inclination of the Earth's axis to the Sun, which took place 8700 years ago [13]. In the post glacial era the global temperature has never been higher than at that time [14]. It was called the Atlantic period of the Holocene [15] [16]. The sea level raised, causing, among others, separation of Britain from the European continent and the emergence of the Persian Gulf, which was then larger than today, extending to 
present lower reaches of the Tigris and Euphrates, which only in later millennia became covered with sediments brought in by these rivers. High temperature was accompanied by heavier than today rainfall in areas north of the Tropic of Cancer, which contributed to the development of vegetation. At these latitudes and at this warmest period the first human civilizations developed on all continents of the northern hemisphere.

Because the perihelion fell on the summer time in the northern hemisphere, unlike today, therefore the northern hemisphere was slightly warmer than the southern one, resulting in temperature in the north of Scandinavia and Siberia even 2 - 6 degrees Celsius higher than at the beginning of the $21^{\text {st }}$ century [17]-[20]. Because of greater inclination of the Earth's axis to the Sun, the Intertropical Convergence Zone (ITCZ) was displaced in the summer more toward the pole of the summer hemisphere. The African monsoon, blowing off the Gulf of Guinea, reached further north, resulting in elevated groundwater level in the Lake Chad basin, whose surface during the maximum range was comparable to today's Germany, and drained into the Atlantic [21]. Additionally, equatorial easterly winds blowing over Africa, related to the Walker circulation, were also stronger as evidenced by the high water levels of great lakes in East Africa, with maximum from 15.3 to 11.5 thousand years ago [22]. This eastern circulation of humid air, called also the East African monsoon [23], provided additional rainfall in the Sahel. Both African monsoons: from the Gulf of Guinea and the East African monsoon were responsible for the high groundwater level in the Lake Chad basin and were delivering moisture into the Sahel and the southern part of the Sahara filling the great aquifers which remain in the Sahara until today. It was the "green Sahara" period. Although in the literature it is mentioned that the cause of the increased precipitation in the northern part of the Sahara is unknown [22], the hypothesis can be put forward that the precipitation in the northern Sahara could have been greater because in winter, due to greater inclination of the Earth's axis, westerlies blowing at mid-latitudes (MLW) might have reached further south than today. More abundant vegetation caused a lower land albedo in horse latitudes and subsequently the solar forcing was greater there and the area was warmer. The energy balance of horse latitudes was more positive than today. Due to a higher solar forcing, air tended to ascend over these areas inhibiting descending air currents in the Hadley cell and trade winds blowing toward the equator. Weaker trade winds were less depriving land of heat and moisture which also contributed to warmer and more humid climate around the Tropic of Cancer. Due to the lower albedo of northern Sahara, the westerlies in the Ferrel cell less deprived heat and moisture from the Tropic of Cancer as well. Because the inclination of the Earth's axis toward the sun was bigger, the range of polar cells could have been smaller in summer and larger in winter. Due to the principle of conservation of energy, weaker trade winds in a Hadley cell might have resulted in weaker westerlies in the Ferrel cell, but they did not, probably because of stronger easterlies in polar cells in winter as well as stronger Walker circulation. Stronger circulation within the northern polar cell in winter could have driven mid-latitudes' westerlies everywhere where the winter Siberian High did not reach. Globally, these westerlies might have been stronger despite their weakening by weaker 
trade winds. In addition, smaller insolation in winter in the northern hemisphere resulted in a greater temperature gradient between the warmer Atlantic and cooler Eurasian continent which could have caused MLW to carry heavier rain and snow. Nowadays, the winter MLW are responsible for most of the annual precipitation in the entire belt stretching from the Mediterranean Sea to the Pamir mountains. During the HCO, precipitation was enough generous to ensure the spread of oak and pistacia forests from the Mediterranean Sea to the Himalayas [24]-[30]. Higher precipitation in Pamir, through Syr Darya and Amu Darya rivers, provided more water in the Aral Sea basin which was larger and connected with the Caspian Sea with the Uzboyriver, a distributory of Amu Darya. High water level in the great lakes of equatorial East Africa suggests that Walker circulation which moves moist air over the Pacific and Atlantic Ocean from east to west along the equator and which nowadays loses its continuity over the western Indian Ocean during the summer and moves most of air in the opposite direction, toward the Deccan, had at that time more uniform course from east to west around the equator. The fact that this so-called East African monsoon between $8 \mathrm{ka}$ to $10 \mathrm{ka}$ ago did not cover Lake Malawi (which level was about 100 meters lower than today [31]) while at the same time the water level in Lake Turkana was the highest so that it allowed this lake to constitute one of sources of the Nile [32] proves that the East African monsoon was also directed more to the north than today. This stronger equatorial wind could have been responsible for stronger rainfall in the Nile basin (including Lake Turkana) and in the Lake Chad basin which both outflowed into the Atlantic. Together with larger than today discharge of the Congo river, this could have resulted in a negative balance of water in the Indian Ocean and consequently in stronger currents in the straits of Indonesia, where water from the Pacific to the Indian Ocean is transported. This could have reduced overheating of the western Pacific Ocean and prevented the creation of the ENSO phenomenon. Heavy precipitation at mid-latitudes, which in winter reached Pamir mountains and the western part of Tibet as well as basins to the north of Tibet (Tarim, Qaidam and Dzungarian basins), resulted in a higher groundwater level, a higher level of lakes and higher cloudiness in the Asia's interior. For this reason, the summer low-pressure area in Asia could have been weaker and thus less affecting the western part of the Indian Ocean where the humid air to a greater extent than at present moved to the west, over Africa and the Arabian Peninsula [33]. The assumption that monsoons in the $\mathrm{HCO}$ were weaker than today stays in conflict with the common theory that during $\mathrm{HCO}$ monsoons were stronger than today. Proponents of the theory of stronger monsoon in the HCO point out that the amount of sediment on the bottom of the Bay of Bengal was larger at that time [34]. However, an increased amount of sediment could have been caused by a more western direction of the India monsoon, therefore more water was flowing through the Ganges and less through Brahmaputra. Since the soft lowland surface on which the Ganges flows is more prone to donating sediment than the rocky mountains through which Brahmaputra goes, therefore the amount of sediment carried by these two rivers together could have been larger, despite weaker monsoon. 


\section{The Beginning of the Neolithic Revolution}

The Neolithic Revolution is defined as a period in the history of mankind which brought the domestication of animals and crops, especially cereals. It began independently in several locations. Sorghum was cultivated in western Africa. In the Middle East: wheat, barley, peas, lentils, flax and figs were domesticated. In India: cotton, sesame and dates. In northern China millet and soybean, and in southern China: rice and hemp. Simultaneously several animal species were domesticated (pigs, cows, buffalo, goats, donkeys, camels, horses, etc.). Since then, the fate of humanity depends on the effectiveness in the struggle to expand and maintain areas suitable for growing crops and breeding animals. Skills to act collectively, learned by hunters-gatherers, which allowed people to spread throughout the globe, guaranteed success in agriculture and animal breeding as well. Abundance of food allowed a demographic explosion, which led to the creation of specializations and eventually to the formation of cities and states. Another achievement of civilization was the invention of writing, which, like the domestication of cereals and animals, proceeded independently in Egypt, the Middle East and China. Reading these records provides an information about life and events in the Neolith.

The earliest cradle of civilization is considered to be the so-called "Fertile Crescent" which extends from the Zagros Mountains in western Iran, through Mesopotamia, Syria and Palestine to Egypt. This civilization was based on the cultivation of cereals showing long-day photoperiodic responses (barley, wheat, oats and rye) [35]. These cereals do not require summer rain, and their cultivation can base on the moisture stored in winter (dryland farming). Distribution of the first large cities of the Neolith in northern Iraq and eastern Syria proves that during the Neolithic Revolution the annual precipitation in this region was higher than today. In turn, the type of domesticated plants argues for the fact that precipitation occurred predominantly in winter when the prevailing winds blew from the west and high yields could initially be achieved only at the beginning of summer unless summer rains also occurred. Thanks to the further development of civilization and the construction of irrigation canals, harvesting twice a year could have become the rule but the evidence for the developed network of irrigation canals dates back to the Bronze Age which came later.

\section{The Collapse of Neolithic Civilizations and Its Relationship with 4.2 ka Climatic Event}

Research of fossil pollen shows that after the withdrawal of the last ice age, before the advent of the Neolithic Revolution, oaks, cedars and pistacia were common in the area [24] [25] [27]-[30] [36]. Today, only small pieces of natural pistacia forests can be found there [37]. The presence of trees and shrubs in the vicinity of the first cultivated fields protected the latter from drying and increased chance of rain in the summer because their lower albedo was causing convection of air masses which contributed to convective rains. Weiss et al. hypothesized that a decrease in precipitation was a cause of the collapse of the first Neolithic civilization in northern Mesopotamia and eastern Syria and of shifting the center of civilization to the south where communities in the 
lower reaches of the Tigris and Euphrates learned how to build irrigation canals and exploit snowmelt water flowing from mountains [6]. In the early Neolith, in the absence of irrigation canals, basing agriculture on the spring overflows of the Tigris and Euphrates would not allow for the development of large Neolithic cities which were located far from the major rivers. It is very likely that at the beginning of the Neolithic Revolution agriculture in the Middle East was based to some extent also on the summer rainfall. The evidence for this comes especially from the area of today's Pakistan [36] and the Nile delta [38]. These rains could come from the convection of moist air originating from the steaming soil, as well as MLW. Additionally, due to greater inclination of the axis of Earth to the Sun, summer monsoon reached further north and therefore eddies guided the summer monsoon rain over Syria and Mesopotamia more frequently than currently.

The disaster which occurred 4200 years ago, caused by over a century of cooling and drought, was characterized not only by the decline in the discharge of the Nile but also by the reduction of ratio of rainfall in the White Nile basin to the rainfall in the Blue Nile basin [39]. This reflects weakening of the East African monsoon. This weakening could have been caused by an increased strength of the summer Indian monsoon, driven by a stronger low pressure area emerging in the summer in the central part of Asia which increased its suction force and began to pick up the moist air from the Indian Ocean (a northern branch of the East African monsoon) to a greater extent and direct it to the northeast. Changing the main vector of the Indian summer monsoon to the east caused a reduction in the precipitation in the Indus basin and an increase in the basins of the Ganges and Brahmaputra. Due to an arched shape of the Himalayas ridge, even a small shift of the main monsoon vector to the east results in a disproportionately larger shift of masses of moist air to the east and moving them away from the Western Himalayas and Pamir (Figure 1). This may explain the collapse of the Neolithic civilization in northern India. The most impressive example of this civilization are ruins of Mehrgarh in Baluchistan, dated 7000 - 2500 years BCE, which are located several hundred kilometers north of the Indus River, at the foot of mountains near the border with Afghanistan, in areas which are nowadays semi-arid. This location suggests that at that time rain nearby Merhgarh was regular and sufficient to support the development of big cities and civilization.

Evidence of the influence of $4.2 \mathrm{ka}$ event on Neolithic civilizations' collapse was also found in China. Remnants of the earliest civilizations in China are located mainly in northern highlands, on the tributaries of the Huang-he, on the Loess Plateau and in today's Inner Mongolia. The Yangshao, Qijia, Laohushan and Longshan cultures existed in areas that today suffer from water shortages. This proves that the East Asian monsoon once reached about one thousand kilometers further north than today [40]-[45]. Both the civilizations in northern China and Inner Mongolia based on the cultivation of millet as well as the civilizations of the Yangtze River which cultivated rice could develop thanks to regular and abundant summer rain which favored the cultivation of these cereals (short-day plants). Probably heavy summer monsoon rains limited the possibility 


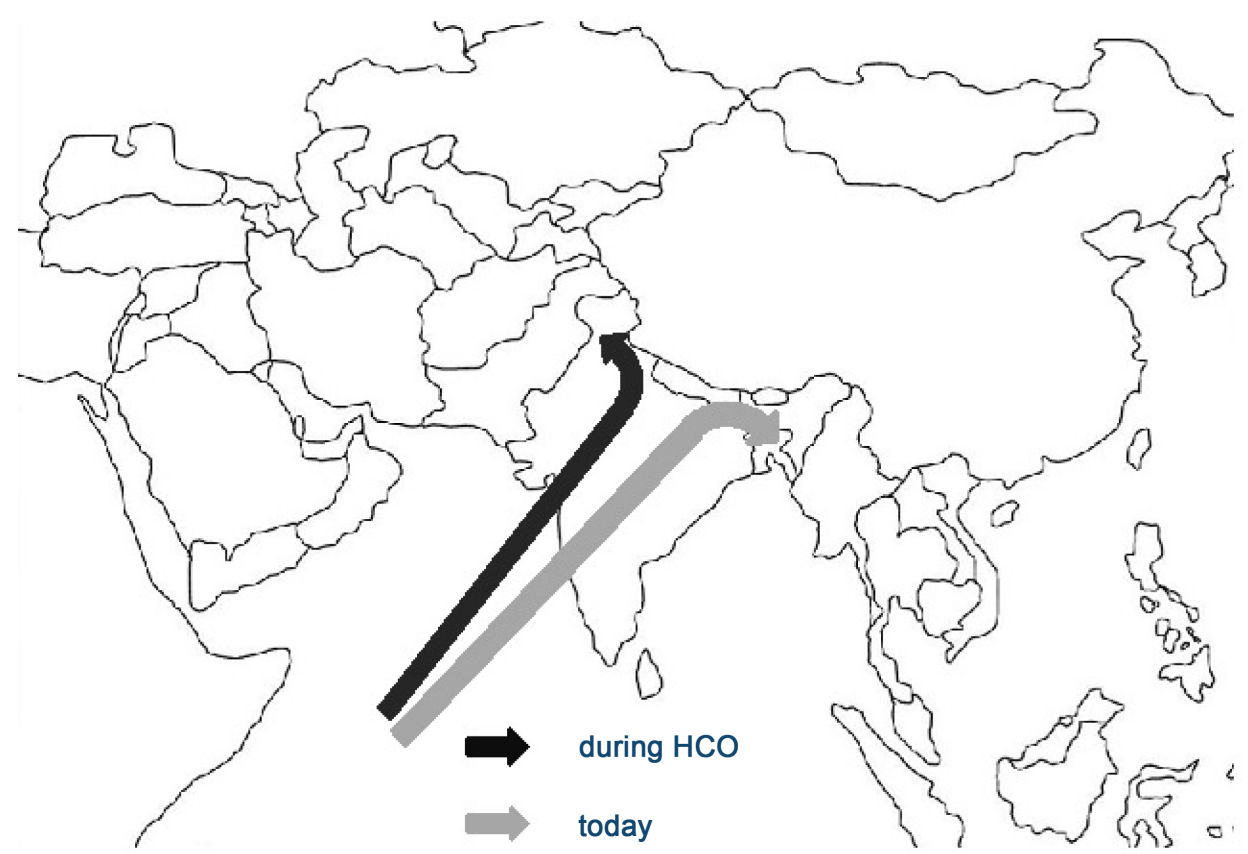

Figure 1. The suggested course of the Indian summer monsoon during HCO and at present. Due to an arched shape of the Himalayas a slight shift of the vector of the monsoon to the east redirected this monsoon much farther to the east.

to build human habitations on the North China Plain. Only the ability to build canals enabled humans to exploit agriculturally Huang-he plains which previously had been often flooded marshes. Legends written in the Bamboo Annals and the scientific research show that the first system of irrigation canals, which aimed to distribute the summer floods' water, was built about 4100 years ago, after inhabitants have moved from highlands eastward into alluvial territories on the Yellow River [46]. This happened when drought forced the people to leave their highland headquarters. Both northern highland civilizations based on the cultivation of millet and southern civilization based on cultivation of rice collapsed at about the same time that is about 4000 years ago. It is believed that the cause of the fall of northern civilization were alternating droughts and floods [47] as well as cooling of the climate while the cause of the collapse of southern civilization were violent floods [48]. This reflects the decrease in the coverage area of the East Asian monsoon in northern China and shifting its main vector to the south, to the basin of the Yangtze River.

\section{The Possible Impact of the Neolithic Revolution on Climate Change}

It is interesting that a dry and cold period in northern China started almost two centuries before the onset of the similar period in the Middle East. This suggests that the solar activity was not the only cause of the development of this event. Therefore, a question arises whether the Neolithic Revolution, which brought the development of agriculture, animal husbandry and demographic explosion, posing a threat to the naturally 
occurring ecosystems, might have contributed to the global climate change. Conversion of naturally occurring forests and savannas to fields and pastures could have resulted in a progressive desertification, increasing albedo, changing the direction of airflow from ascending to descending, the disappearance of summer rainfall and the increasing dependence of agriculture on the spring snowmelt in mountains. Archaeological research indicates that the first large cities of Mesopotamia were abandoned almost simultaneously about 4200 years ago, at a time that coincided with a period of extensive desertification of areas to the east of the Mediterranean Sea. Features of this desertification were found in studies of stalactites and stalagmites in caves [4] [49] [50] and marine sediments [5] [51]-[54]. The rapid desertification of the Middle East which took place about 4200 years ago coincided with the rapid global cooling of the climate [6] [7] [55] and was probably related to Bond cycle. However, the cooling related to Bond event 3 proceeded more rapidly than usual. Probably the need to feed a large human population during the long-term drought and cold forced people to more intense clearing of forests and trees on the savannah, both for fuel and construction, as well as to increase the area suitable for sowing and pastures. Due to drought lasting about 150 years, these forests and trees on the savannah had no possibility of rebirth. Because their cutting down caused an increased albedo and more negative energy balance across several million square kilometers-from the Atlantic to the Pacific along the Tropic of Cancer-therefore it could have exacerbated climate cooling not only at these latitudes but also globally. The disappearance of the savannah from the today's Sahara and the Arabian Peninsula as well as cedar-oak-pistacia forests from the Near East, together with the expansion of the Gobi and Ordos Desert in China, increased the albedo of these areas by about 10 percentile points (forest albedo: 5 - 15, farmland albedo: 15 - 25, savannah albedo: 15 - 20, desert albedo: 25 - 30). However, an exact calculation of the impact of changes in earth's surface albedo on global climate is impossible because the planet's albedo also depends on the amount and type of clouds and data on this topic are lacking.

The question arises whether at the end of the Holocene mankind could have contributed to global climate cooling and desertification since centers of civilization were spaced apart by several thousand kilometers and population density was relatively low. It is estimated that during the Neolith the world population has grown from about 50,000 to about 10 million, i.e. 200-fold [56] but was it enough to cause global climate changes? It should be noted that this rapid population growth was concentrated in a belt located north of the Tropic of Cancer where the population could have increased even more, e.g. 1000-fold or more. This growth is demonstrated by the size of urban populations which often exceeded 50,000 [57]. The reason why mankind could have influenced global cooling was localization of Neolithic civilizations in areas prone to desertification. It should be reiterated that the Neolithic Revolution involved not only a relatively small valleys around rivers, where the cultivation of cereals progressed, but also the vast steppe and savanna where the animal husbandry was expanding. Both of these fields of human expansion caused the increase in albedo of inhabited areas which 
was exaggerated in periods of drought. Location of all Neolithic civilizations on a similar latitude could have caused a withdrawal of MLW to the north as well as changing the pattern of monsoons in the mechanism described later in this article.

\section{Global Climate Changes after the 4.2 ka Event}

After Bond event 3 stopped, climate only partially returned to the previous state. After about 150 years of drought and cooling, rains and warmer climate returned which suggests that deforestation was not the only factor cooling the climate. However, research on the Dead Sea and lakes in Iran reveals that the amount of precipitation has never returned to the levels before $4.2 \mathrm{ka} \mathrm{[58]} \mathrm{[59].} \mathrm{Permanent} \mathrm{changes} \mathrm{have} \mathrm{taken} \mathrm{place} \mathrm{in}$ Africa in the form of a reduction in the Lake Chad area and remarkable reduction in rainfall in the basins of Turkana, Victoria and Alberta lakes [22]. In India monsoon has moved to the southeast, causing desertification of the northern part of the subcontinent and Baluchistan. In China the monsoon has decreased in the north and increased in the south. This demonstrates the permanent change in global air circulation, a possible reason for which was enhancing of low-pressure area over the interior of Asia in summer caused by progressive desertification, in the mechanism described above.

Over the next millennia, this shift of direction of monsoons proceeded further: the Yellow Nile which once confluenced the mainstream Nile close to the Great Bend in Sudan [60] dried up completely about 1000 years BCE. East Asian monsoon was further retreating to the south, causing droughts in the north [61]-[63] and an excess of water in the south of China [64]. In the Middle East the precipitation carried by western circulation, which only 3 thousand years ago supplied with water the Persian Empire that was home to about $40 \%$ of what was then the world's population [65], gradually retreated to the north not only causing desertification of former Persian Empire but also progressive drying of the Aral Sea which even accelerated during the $20^{\text {th }}$ century as a consequence of an extensive cotton production. This cannot be explained merely by a change of inclination of the axis of Earth to the Sun, which is a slower process. Decreasing the inclination by $1^{\circ}$ moves tropics towards the equator by about $111 \mathrm{~km}$, which means that since the HCO tropics have shifted toward the equator by about 150 $\mathrm{km}$. Meanwhile, monsoon zone in Africa, India and China has retreated to the south by several hundred kilometers. Low-resolution CCM0 (Community Climate Model 0 of the National Center for Atmospheric Research) computerized model results also show systematic northward deviation from modern conditions, especially in China [66]. Moreover, in spite of some predictions [67], recent global warming has not produced an increase of precipitation in areas at risk of drying which proves that increase in the air temperature, SST and sea level are not the only factors determining the amount of precipitation over land but the extent of precipitation zone of MLW and the course of monsoons in subtropical regions are crucial to it. Both the ranges of MLW and monsoons have retreated steadily since the HCO and this process was aggravated in colder periods, especially during the Holocene 4.2 ka event. 


\section{The Role of Tibetan Plateau in Directing the Course of the Monsoons}

As indicated earlier, in the era of HCO the moist MLW were stronger and reached farther east than today. Throughout the Holocene annual precipitation in Pamir mountains derives from this circulation [68]. The impact of this circulation on precipitation in the western part of the Himalayas and western part of Tibet is also significant [69].

The climate of the Tibetan Plateau during HCO was more humid than it is now [40] [70]-[73] due to 1) an increased precipitation carried by the western circulation, 2) direction of the Indian monsoon to western rather than eastern part of the Himalayas and 3) higher humidity of areas to the north of the Tibet. The latter contributed to precipitation carried by northern winds blown by the Siberian High in winter. They guaranteed heavier snowfall and longer duration of snow cover and subsequently greater cloudiness over Tibet. Higher humidity in Tibet resulted in higher atmospheric pressure over this plateau. During HCO, the presence of larger than today endorheic lakes and higher humidity guaranteed thicker and longer lasting snow cover which was responsible for higher albedo, and for relatively lower temperature of Tibet compared to the temperature of areas surrounding it. The reciprocal of this phenomenon is observed today, when glaciers' melting in Tibet is accompanied by more rapid warming of the climate there than globally [74]. A predominant opinion in the literature is that the higher humidity in Tibet in the HCO was a result of greater extent of the East Asian monsoon. Against this thesis is the fact that higher atmospheric pressure over Tibet, due to its higher humidity, must have been weakening the low pressure area over it and thus might have reduced the strength and extent of monsoon in Tibet. Moreover, higher air pressure over Tibet could have repelled the East Asian monsoon to the north and Indian monsoon to the west.

Because Tibet is surrounded in the south by higher mountains (Himalayas) than in the north (Kunlun), the impact of relatively dry, winter northern winds as well as western air circulation on the formation of snowfall and glaciers is significant compared with the southern monsoon. Albeit the latter is more humid, it blows during the summer and therefore brings rain rather than snow and loses most of the moisture on the southern slopes of the Himalayas. The summer monsoon reaches mostly to the southern and eastern parts of the Tibetan Plateau, which are less elevated above the sea level than the western and northern parts and thus less favor formation of glaciers. Moreover, this area is drained into the Bay of Bengal and the South China Sea, which does not help to keep summer rainfall water in Tibet.

In the era of HCO, the precipitation in mountains of Central Asia (Tien-Shan, Kunlun) and in the northern part of the Tibetan Plateau was greater than today, allowing the existence of forest [75]-[77]. It is believed that the presence of forests in northern Tibet at that time proves the greater range of the monsoon because the prerequisite for the existence of such forests is greater summer rainfall. However, the source of summer rains could have been also evaporating snowmelt water which formed clouds, providing 
summer rain and reflecting solar radiation. These clouds protected Tibet from heat generated by almost vertically falling summer solar rays and formed over it a "cap" of colder, denser atmosphere. It was this slightly higher than today atmospheric pressure over Tibet which could have been responsible for directing the southern monsoon more to the west and the East Asian monsoon further north (Figure 2).

\section{Turkmen-Tibetan Feedback}

Larger than today precipitation in Pamir mountains provided enough water to Amu Darya and Syr Darya, maintaining the Aral Sea. The evaporation from the Aral Sea contributed to a significant portion of precipitation in Tien-Shan mountains. The East Asian monsoon which reached further north more abundantly supplied basins of the Huang-he and basins of endorheic rivers flowing from Qilian mountains toward the Gobi desert as well as lakes in the northern part of the Tibetan Plateau: the Qinghai Lake and several lakes in the Qaidam Basin. During the winter monsoon, moisture from lakes in the Qaidam and Tarim Basins was carried to Tibet by Siberian High winds, creating snow cover. Lake Lobi-Nur was more abundantly supplied by Tarim River flowing from the western Himalayas and its tributaries from Tien-Shan mountains. This feedback mechanism was very delicate because it carried relatively small amount of water and was protected by a thin layer of the atmosphere over Tibet. This feedback mechanism, which can be called Turkmen-Tibetan feedback (Figure 2), has gradually weakened over the millennia because of shifting the westerlies to the north,

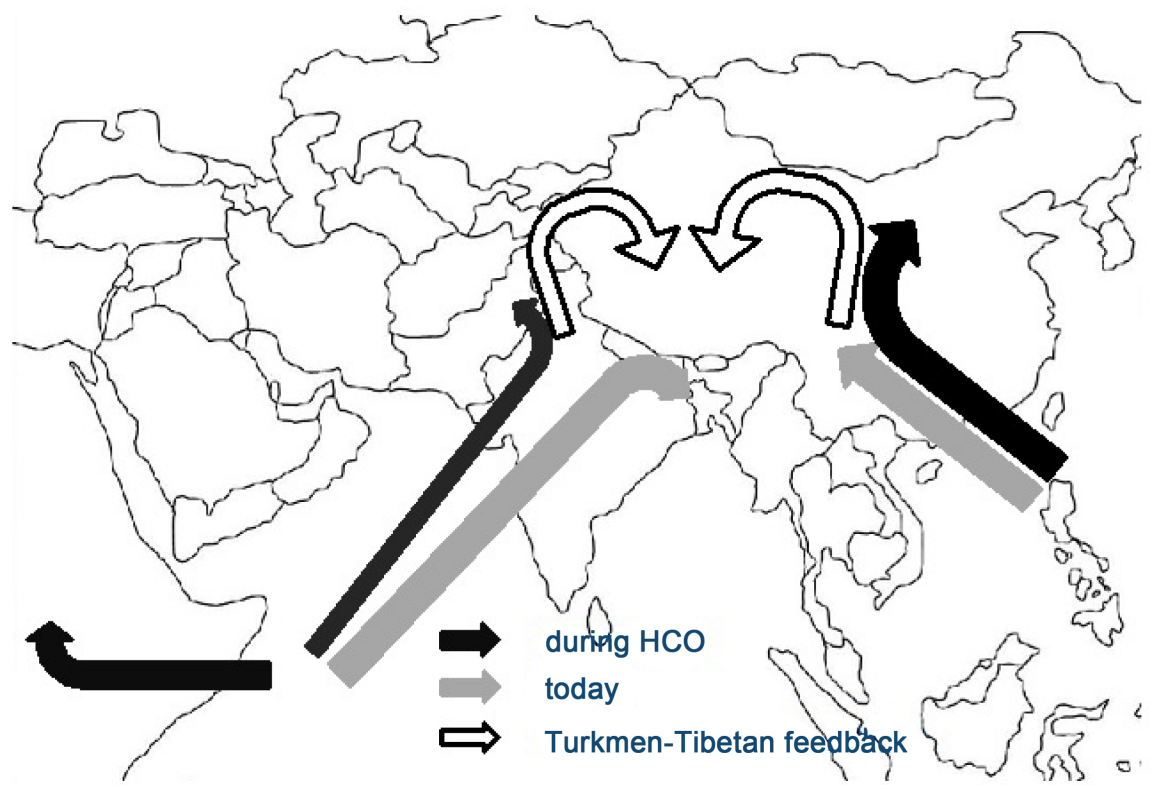

Figure 2. A hypothetic course of monsoons in Asia and Eastern Africa during HCO and today. Due to weaker Indian summer monsoon, the East African monsoon might have been stronger than today. Higher humidity of Tibet could have been caused mainly by stronger MLW and, to a lesser extent, by stronger winter precipitation carried by winter monsoon while the influence of summer monsoons on precipitation in Tibet could have been weaker than today. 
shifting the vector of the Indian monsoon to the east and subsequent loss of water from the large Asian endorheic basins.

\section{Summary}

1) Desertification and deforestation of vast areas along the Tropic of Cancer could have caused an increased albedo and enhanced trade winds, exacerbating desertification of horse latitudes in a positive feedback mechanism.

2) The 4.2 ka global cooling event could have been aggravated by extensive changes in ecosystems caused by humans along the Tropic of Cancer.

3) Southern and East Asian monsoons in HCO could have been weaker, not stronger than today and only their vectors could have bypassed Tibet.

4) Higher humidity of Tibet could have been crucial factor for driving the Indian monsoon more to the west and East Asian monsoon more to the north.

5) Higher humidity of Tibet could have been determined by a stronger precipitation carried by MLW, more western direction of the summer Indian monsoon and a small but significant winter precipitation carried by the winter monsoon.

6) An important reason for the development of "green Sahara" phenomenon could have been stronger than previously assumed northern branch of Walker circulation (East African monsoon).

7) Stronger East African monsoon could have prevented the development of ENSO phenomenon through the creation of negative water balance in the Indian Ocean.

Confirmation of these hypotheses requires further research on the historical level of lakes in Africa, Central Asia and Tibet, the extend of glaciers in Tibet, Tien Shan and Pamir mountains as well as research on historical flora and fauna of East Africa and the Sahel, southern part of the Arabian Peninsula and endorheic basins in Asia which may enable scientists to calculate the amount of precipitation and the P/E ratio and to include these factors in computerized climate models. In the future computerized climate models the more complete Walker circulation along the equator, repulsion of the Indian monsoon to the west and the East Asian monsoon to the north by greater snow cover as well as greater cloudiness in Tibet should be taken into account.

Understanding mechanisms responsible for the withdrawal of monsoons and MLW from the horse latitudes may provide the key to fighting the negative consequences of recent global warming, especially unfavorable distribution of precipitation and rising sea level. Realizing the fact that mankind could have affected global climate change not only during the last century but also in the remote past may help us to learn how to better protect Earth from an adverse impact of our activities, and even how to change the climate of the Planet in the direction desired by us.

\section{Acknowledgements}

I would especially like to thank Prof. Tadeusz Górski from the Institute of Soil Science and Plant Cultivation in Puławy, Poland, for his support and encouragement through- 
out preparing this article. I thank Dr. Łukasz Dominiak from the Nicolaus Copernicus University in Torun, Poland and two anonymous reviewers for their careful reviews and comments that improved the manuscript.

\section{References}

[1] Collier, J.L., Ed. (1990) Historical Setting, Chad: A Country Study, Library of Congress Country Studies. 2nd Edition, Library of Congress, Washington DC, 13.

[2] Oliver, R. (1999) The African Experience: From Olduvai Gorge to the 21st Century (Series: History of Civilization). Revised Edition, Phoenix Press, London, 39.

[3] Sutton, J.E.G. (1974) The Aquatic Civilization of Middle Africa. Journal of African History, 15, 527-546. http://dx.doi.org/10.1017/S0021853700013864

[4] Drysdale, R., Zanchetta, G., Hellstrom, J., Maas, R., Fallick, A., Pickett, M. and Piccini, L. (2006) Late Holocene Drought Responsible for the Collapse of Old World Civilizations Is Recorded in an Italian Cave Flowstone. Geology, 34, 101-104. http://dx.doi.org/10.1130/G22103.1

[5] Staubwasser, M., Sirocko, F., Grootes, P.M. and Segl, M. (2003) Climate Change at the 4.2 ka BP Termination of the Indus Valley Civilization and Holocene South Asian Monsoon Variability. Geophysical Research Letters, 30. http://dx.doi.org/10.1029/2002gl016822

[6] Weiss, H., Courty, M.-A., Wetterstrom, W., Guichard, F., Senior, L., Meadow, R. and Curnow, A. (1993) The Genesis and Collapse of Third Millennium North Mesopotamian Civilization. Science, 261, 995-1004. http://dx.doi.org/10.1126/science.261.5124.995

[7] Weiss, H. (2000) Beyond the Younger Dryas-Collapse as Adaptation to Abrupt Climatic Change in Ancient West Asia and the Eastern Mediterranean. In: Bawden, G. and Reycraft, R., Eds., Confronting Natural Disaster. Engaging the Past to Understand the Future, University of New Mexico Press, Albuquerque, 75-98.

[8] Bond, G., Showers, W., Cheseby, M., Lotti, R., Almasi, P., Priore, P. and Bonani, G. (1997) A Pervasive Millennial-Scale Cycle in North Atlantic Holocene and Glacial Climates. Science, 278, 1257-1266. http://dx.doi.org/10.1126/science.278.5341.1257

[9] Debret, M., Bout-Roumazeilles, V., Grousset, F., Desmet, M., McManus, J.F., Massei, N. and Trentesaux, A. (2007) The Origin of the 1500-Year Climate Cycles in Holocene NorthAtlantic Records. Climate of the Past Discussions, 3, 679-692. http://dx.doi.org/10.5194/cpd-3-679-2007

[10] Michalek, M.J. (2013) Examining the Progression and Termination of Lake Agassiz (PDF) Michigan State University. https://msu.edu/ michal76/research/407 Geomorphology Lake\%20Agassiz2.pdf

[11] Björck, S., Rundgren, M., Ingolfsson, O. and Vunder, S. (1997) The Preboreal Oscillation around the Nordic Seas: Terrestrial and Lacustrine Responses. Journal of Quaternary Science, 12, 455-466. http://dx.doi.org/10.1002/(SICI)1099-1417(199711/12)12:6<455::AID-JQS316>3.0.CO;2-S

[12] Roland, T.P., Caseldine, C.J., Charman, D.J., Turney, C.S.M. and Amesbury, M.J. (2014) Was There a "4.2 ka Event" in Great Britain and Ireland? Evidence from the Peatland Record. Quaternary Science Reviews, 83, 11-27. http://dx.doi.org/10.1016/j.quascirev.2013.10.024

[13] Perry, C.A. and Hsu, K.J. (2000) Geophysical, Archaeological, and Historical Evidence Support a Solar-Output Model for Climate Change. Proceedings of the National Academy of Sciences, 97, 12433-12438. http://dx.doi.org/10.1073/pnas.230423297 
[14] Viau, A.E., Gajewski, K., Sawada, M.C. and Fines, P. (2006) Millennial-Scale Temperature Variations in North America during the Holocene. Journal of Geophysical Research, 111, D09102. http://dx.doi.org/10.1029/2005jd006031

[15] Blytt, A. (1876) Essay on the Immigration of the Norwegian Flora during the Alternating Rainy and Dry Period, Alb. Cammermayer, Christiana (Oslo).

[16] Sernander, R. (1908) On the Evidence of Post-Glacial Changes of Climate Furnished by the Peat Mosses of Northern Europe. Geologiska Föreningensi Stockholm Förhandlingar, 31, 423-448. http://dx.doi.org/10.1080/11035890909443099

[17] Andreev, A.A., Siegert, C., Klimanov, V.A., Derevyagin, A.Y., Shilova, G.N. and Melles, M. (2002) Late Pleistocene and Holocene Vegetation and Climate on the Taymyr Lowland, Northern Siberia. Quaternary Research, 57, 138-150. http://dx.doi.org/10.1006/qres.2001.2302

[18] Eronen, M. (2013) The Retreat of Pine Forest in Finnish Lapland since the Holocene Climatic Optimum: A General Discussion with Radiocarbon Evidence from Subfossil Pines. Fennia: International Journal of Geography, 157, 93-114.

[19] MacDonald, G.M., Velichko, A.A., Kremenetski, C.V., Borisova, O.K., Goleva, A.A., Andreev, A.A., Aravena, R., et al. (2000) Holocene Treeline History and Climate Change across Northern Eurasia. Quaternary Research, 53, 302-311. http://dx.doi.org/10.1006/qres.1999.2123

[20] Tarasov, P.E., Bezrukova, E.V. and Krivonogov, S.K. (2009) Late Glacial and Holocene Changes in Vegetation Cover and Climate in Southern Siberia Derived from a 15 kyr Long Pollen Record from Lake Kotokel. Climate of the Past, 5, 285-295. http://dx.doi.org/10.5194/cp-5-285-2009

[21] Leblanc, M., Favreau, G., Maley, J., Nazoumou, Y., Leduc, C., Stagnitti, F., Lemoalle, J., et al. (2006) Reconstruction of Megalake Chad Using Shuttle Radar Topographic Mission Data. Palaeogeography, Palaeoclimatology, Palaeoecology, 239, 16-27. http://dx.doi.org/10.1016/j.palaeo.2006.01.003

[22] Gasse, F. (2000) Hydrological Changes in the African Tropics since the Last Glacial Maximum. Quaternary Science Reviews, 19, 189-211. http://dx.doi.org/10.1016/S0277-3791(99)00061-X

[23] Tierney, J.E., Russell, J.M., Damsté, J.S.S., Huang, Y. and Verschuren, D. (2011) Late Quaternary Behavior of the East African Monsoon and the Importance of the Congo Air Boundary. Quaternary Science Reviews, 30, 798-807. http://dx.doi.org/10.1016/j.quascirev.2011.01.017

[24] El-Moslimany, A.P. (1986) Ecology and Late-Quaternary history Of the Kurdo-Zagrosian oak Forest near Lake Zeribar, Western Iran. Vegetatio, 68, 55-63.

[25] Liphschitz, N. and Biger, G. (1990) Ancient Dominance of the Quercus calliprinos-Pistacia palaestina Association in Mediterranean Israel. Journal of Vegetation Science, 1, 67-70. http://dx.doi.org/10.2307/3236054

[26] Naveh, Z. and Dan, J. (1973) The Human Degradation of Mediterranean Landscapes in Israel. In: di Castri, F. and Mooney, H.A., Eds., Mediterranean Type Ecosystems, Volume 7 of the Series Ecological Studies, Springer, Berlin, 373-390. http://dx.doi.org/10.1007/978-3-642-65520-3 22

[27] Niklewski, J. and Van Zeist, W. (1970) A Late Quaternary Pollen Diagram from Northwestern Syria. Acta Botanica Neerlandica, 19, 737-754. http://dx.doi.org/10.1111/j.1438-8677.1970.tb00176.x

[28] Wick, L. (2003) Evidence of Lateglacial and Holocene Climatic Change and Human Impact 
in Eastern Anatolia: High-Resolution Pollen, Charcoal, Isotopic and Geochemical Records from the Laminated Sediments of Lake Van, Turkey. The Holocene, 13, 665-675. http://dx.doi.org/10.1191/0959683603hl653rp

[29] Wright Jr., H.E., McAndrews, J.H. and van Zeist, W. (1967) Modern Pollen Rain in Western Iran, and Its Relation to Plant Geography and Quaternary Vegetational History. Journal of Ecology, 55, 415-443. http://dx.doi.org/10.2307/2257886

[30] Yasuda, Y., Kitagawa, H. and Nakagawa, T. (2000) The Earliest Record of Major Anthropogenic Deforestation in the Ghab Valley, Northwest Syria: A Palynological Study. Quaternary International, 73-74, 127-136. http://dx.doi.org/10.1016/S1040-6182(00)00069-0

[31] Finney, B.P., Scholz, C.A., Johnson, T.C. and Trumbore, S. (1996) Late Quaternary Lake-Level Changes of Lake Malawi. In: Johnson, T.C. and Odada, E.O., Eds., The Limnology, Climatology and Paleoclimatology of the East African Lakes, Gordon and Breach Publishing, Amsterdam, 495-508.

[32] Johnson, T.C. (1996) Sedimentary Processes and Signals of Past Climatic Change in the Large Lakes of the East African Rift Valley. In: Johnson, T.C. and Odada, E.O., Eds., The Limnology, Climatology and Paleoclimatology of the East African Lakes, Gordon and Breach Publishing, Amsterdam, 367-412.

[33] Burns, S.J., Fleitmann, D., Matter, A., Neff, U. and Mangini, A. (2001) Speleothem Evidence from Oman for Continental Pluvial Events during Interglacial Periods. Geology, 29, 623626. http://dx.doi.org/10.1130/0091-7613(2001)029<0623:SEFOFC >2.0.CO;2

[34] Kudrass, H.-R., Hofmann, A., Doose, H., Emeis, K.-C. and Erlenkeuser, H. (2001) Modulation and Amplification of Climatic Changes in the Northern Hemisphere by the Indian Summer Monsoon during the Past 80 k.y. Geology, 29, 63-66. http://dx.doi.org/10.1130/0091-7613(2001)029<0063:MAAOCC >2.0.CO;2

[35] Junges, W. (1957) Die jährliche Niederschlagsverteilung als entscheidender Faktorbei der photoperiodischen Anpassung der Pflanzen. Gartenbauwissenschaft, 22, 527-540.

[36] Djamali, M., Akhani, H., Andrieu-Ponel, V., et al. (2010) Indian Summer Monsoon Variations Could Have Affected the Early-Holocene Woodland Expansion in the Near East. The Holocene, 20, 813-820. http://dx.doi.org/10.1177/0959683610362813

[37] Pourreza, M., Shaw, J.D. and Zangeneh, H. (2008) Sustainability of Wild Pistachio (Pistacia atlantica Desf.) in Zagros Forests, Iran. Forest Ecology and Management, 255, 3667-3671. http://dx.doi.org/10.1016/j.foreco.2008.01.057

[38] Cheddadi, R. and Rossignol-Strick, M. (1995) Eastern Mediterranean Quaternary Paleoclimates from Pollen and Isotope Records of Marine Cores in the Nile Cone Area. Paleoceanography, 10, 291-300. http://dx.doi.org/10.1029/94PA02672

[39] Stanley, J.D., Krom, M.D., Cliff, R.A. and Woodward, J.C. (2003) Short Contribution: Nile Flow Failure at the End of the Old Kingdom, Egypt: Strontium Isotopic and Petrologic Evidence. Geoarchaeology, 18, 395-402. http://dx.doi.org/10.1002/gea.10065

[40] An, C.B., Feng, Z.D. and Barton, L. (2006) Dry or Humid? Mid-Holocene Humidity Changes in Arid and Semi-Arid China. Quaternary Science Reviews, 25, 351-361. http://dx.doi.org/10.1016/j.quascirev.2005.03.013

[41] Jiang, W., Guo, Z., Sun, X., Wu, H., Chu, G., Yuan, B., Guiot, J., et al. (2006) Reconstruction of Climate and Vegetation Changes of Lake Bayanchagan (Inner Mongolia): Holocene variability of the East Asian Monsoon. Quaternary Research, 65, 411-420. http://dx.doi.org/10.1016/j.yqres.2005.10.007

[42] Long, H., Lai, Z., Wang, N. and Li, Y. (2010) Holocene Climate Variations from Zhuyeze Terminal Lake Records in East Asian Monsoon Margin in Arid Northern China. Quater- 
nary Research, 74, 46-56. http://dx.doi.org/10.1016/j.yqres.2010.03.009

[43] Maher, B.A. (2008) Holocene Variability of the East Asian Summer Monsoon from Chinese Cave Records: A Re-Assessment. The Holocene, 18, 861-866. http://dx.doi.org/10.1177/0959683608095569

[44] Peng, Y., Xiao, J., Nakamura, T., Liu, B. and Inouchi, Y. (2005) Holocene East Asian Monsoonal Precipitation Pattern Revealed by Grain-Size Distribution of Core Sediments of Daihai Lake in Inner Mongolia of North-Central China. Earth and Planetary Science Letters, 233, 467-479. http://dx.doi.org/10.1016/j.epsl.2005.02.022

[45] Xiao, J., Xu, Q., Nakamura, T., Yang, X., Liang, W. and Inouchi, Y. (2004) Holocene Vegetation Variation in the Daihai Lake Region of North-Central China: A Direct Indication of the Asian Monsoon Climatic History. Quaternary Science Reviews, 23, 1669-1679. http://dx.doi.org/10.1016/j.quascirev.2004.01.005

[46] Kwang-Chih, C. (2008) China on the Eve of the Historical Period. Cambridge Histories Online, Cambridge University Press, Cambridge. http://isites.harvard.edu/fs/docs/icb.topic787469.files/camb\%20hist\%20china\%2054-73.pdf

[47] Huang, C.C., Pang, J., Zha, X., Su, H. and Jia, Y. (2011) Extraordinary Floods Related to the Climatic Event at 4200 a BP on the Qishuihe River, Middle Reaches of the Yellow River, China. Quaternary Science Reviews, 30, 460-468. http://dx.doi.org/10.1016/j.quascirev.2010.12.007

[48] Wenxiang, W. and Tungsheng, L. (2004) Possible Role of the "Holocene Event 3" on the Collapse of Neolithic Cultures around the Central Plain of China. Quaternary International. 117, 153-166. http://dx.doi.org/10.1016/S1040-6182(03)00125-3

[49] Bar-Matthews, M., Ayalon, A. and Kaufman, A. (1998) Middle to Late Holocene (6,500 yr. Period) Paleoclimate in the Eastern Mediterranean Region from Stable Isotopic Composition of Speleothems from Soreq Cave, Israel. In: Issar, A.S. and Brown, N., Eds., Water, Environment and Society in Times of Climatic Change, Volume 31 of the Series Water Science and Technology Library, Springer, Berlin, 203-214.

[50] Fleitmann, D., Burns, S.J., Mangini, A., Mudelsee, M., Kramers, J., Villa, I., Matter, A., et al. (2007) Holocene ITCZ and Indian Monsoon Dynamics Recorded in Stalagmites from Oman and Yemen (Socotra). Quaternary Science Reviews, 26, 170-188. http://dx.doi.org/10.1016/j.quascirev.2006.04.012

[51] Arz, H.W., Lamy, F. and Pätzold, J. (2006) A Pronounced Dry Event Recorded around 4.2 ka in Brine Sediments from the Northern Red Sea. Quaternary Research, 66, 432-441. http://dx.doi.org/10.1016/j.yqres.2006.05.006

[52] Cullen, H.M., Hemming, S., Hemming, G., Brown, F.H., Guilderson, T. and Sirocko, F. (2000) Climate Change and the Collapse of the Akkadian Empire: Evidence from the Deep Sea. Geology, 28, 379-382. http://dx.doi.org/10.1130/0091-7613(2000)28<379:CCATCO $>2.0$. CO;2

[53] Gupta, A.K., Anderson, D.M. and Overpeck, J.T. (2003) Abrupt Changes in the Asian Southwest Monsoon during the Holocene and Their Links to the North Atlantic Ocean. Nature, 421, 354-357. http://dx.doi.org/10.1038/nature01340

[54] Mayewski, P.A., Rohling, E.E., Stager, J.C., Karlén, W., Maasch, K.A., Meeker, L.D., Lee-Thorp, J., et al. (2004) Holocene Climate Variability. Quaternary Research, 62, 243-255. http://dx.doi.org/10.1016/j.yqres.2004.07.001

[55] Staubwasser, M. and Weiss, H. (2006) Holocene Climate and Cultural Evolution in Late Prehistoric-Early Historic West Asia. Quaternary Research, 66, 372-387.

http://dx.doi.org/10.1016/j.yqres.2006.09.001 
[56] Hassan, F.A. and Sengel, R.A. (1973) On Mechanisms of Population Growth during the Neolithic. Current Anthropology, 14, 535-542. http://dx.doi.org/10.1086/201380

[57] Chase-Dunn, C., Alvarez, A. and Pasciuti, D. (2005) Power and Size: Urbanization and Empire Formation in World-Systems since the Bronze Age. In: Chase-Dunn, C. and Anderson, E., Eds., The Historical Evolution of World-Systems, Palgrave Macmillan, Basingstoke, 92-112. http://dx.doi.org/10.1057/9781403980526 5

[58] Enzel, Y., Bookman, R., Sharon, D., Gvirtzman, H., Dayan, U., Ziv, B. and Stein, M. (2003) Late Holocene Climates of the Near East Deduced from Dead Sea Level Variations and Modern Regional Winter Rainfall. Quaternary Research, 60, 263-273.

http://dx.doi.org/10.1016/j.yqres.2003.07.011

[59] Hamzeh, M.A., Gharaie, M.H.M., Lahijani, H.A.K., Djamali, M., Harami, R.M. and Beni, A.N. (2016) Holocene Hydrological Changes in SE Iran, A Key Region between Indian Summer Monsoon and Mediterranean Winter Precipitation Zones, as Revealed from a Lacustrine Sequence from Lake Hamoun. Quaternary International, 408, 25-39. http://dx.doi.org/10.1016/j.quaint.2015.11.011

[60] Keding, B. (2000) New Data on the Holocene Occupation of the Wadi Howar Region (Eastern Sahara/Sudan). Studies in African Archaeology, 7, 89-104.

[61] Jiang, T., Zhang, Q., Blender, R. and Fraedrich, K. (2005) Yangtze Delta Floods and Droughts of the Last Millennium: Abrupt Changes and Long Term Memory. Theoretical and Applied Climatology, 82, 131-141. http://dx.doi.org/10.1007/s00704-005-0125-4

[62] Wang, H., Yang, Z., Saito, Y., Liu, J.P. and Sun, X. (2006) Interannual and Seasonal Variation of the Huanghe (Yellow River) Water Discharge over the Past 50 Years: Connections to Impacts from ENSO Events and Dams. Global and Planetary Change, 50, 212-225. http://dx.doi.org/10.1016/j.gloplacha.2006.01.005

[63] Wang, Y. and Zhou, L. (2005) Observed Trends in Extreme Precipitation Events in China during 1961-2001 and the Associated Changes in Large-Scale Circulation. Geophysical Research Letters, 32, Article ID: L09707. http://dx.doi.org/10.1029/2005GL023769

[64] Zhang, S.Q. and Li, S.Q. (1994) The Influence of Fluctuation of Global Temperature on Precipitation in China. Quarterly Journal of Applied Meteorology, 5, 333-339. (In Chinese with English Abstract)

[65] Guinness World Records. Largest Empire by Percentage of World Population. http://www.guinnessworldrecords.com/world-records/largest-empire-by-percentage-of-wo rld-population/

[66] An, Z., Porter, S.C., Kutzbach, J.E., Xihao, W., Suming, W., Xiaodong, L., Weijian, Z., et al. (2000) Asynchronous Holocene Optimum of the East Asian Monsoon. Quaternary Science Reviews, 19, 743-762. http://dx.doi.org/10.1016/S0277-3791(99)00031-1

[67] Zhang, Z., Cazelles, B., Tian, H., Stige, L.C., Bräuning, A. and Stenseth, N.C. (2009) Periodic Temperature-Associated Drought/Flood Drives Locust Plagues in China. Proceedings of Royal Society B, 276, 823-831. http://dx.doi.org/10.1098/rspb.2008.1284

[68] Zech, R., Abramowski, U., Glaser, B., Sosin, P., Kubik, P. W. and Zech, W. (2005) Late Quaternary Glacial and Climate History of the Pamir Mountains Derived from Cosmogenic 10 Be exposure Ages. Quaternary Research, 64, 212-220. http://dx.doi.org/10.1016/j.yqres.2005.06.002

[69] Benn, D.I. and Owen, L.A. (1998) The Role of the Indian Summer Monsoon and the Mid-Latitude Westerlies in Himalayan Glaciation: Review and Speculative Discussion. Journal of the Geological Society, 155, 353-363. http://dx.doi.org/10.1144/gsigs.155.2.0353

[70] Feng, Z., An, C.B. and Wang, H.B. (2006) Holocene Climatic and Environmental Changes 
in the Arid and Semi-Arid Areas of China: A Review. The Holocene, 16, 119-130. http://dx.doi.org/10.1191/0959683606hl912xx

[71] Jin, Z.D., Wu, Y., Zhang, X. and Wang, S. (2005) Role of Late Glacial to Mid-Holocene Climate in Catchment Weathering in the Central Tibetan Plateau. Quaternary Research, 63, 161-170. http://dx.doi.org/10.1016/j.yqres.2004.09.012

[72] Phadtare, N.R. (2000) Sharp Decrease in Summer Monsoon Strength 4000-3500 calyr BP in the Central Higher Himalaya of India Based on Pollen Evidence from Alpine Peat. Quaternary Research, 53, 122-129. http://dx.doi.org/10.1006/qres.1999.2108

[73] Yanhong, W., Lücke, A., Zhangdong, J., Sumin, W., Schleser, G.H., Battarbee, R.W. and Weilan, X. (2006) Holocene Climate Development on the Central Tibetan Plateau: A Sedimentary Record from Cuoe Lake. Palaeogeography, Palaeoclimatology, Palaeoecology, 234, 328-340. http://dx.doi.org/10.1016/j.palaeo.2005.09.017

[74] Liu, X. and Chen, B. (2000) Climatic Warming in the Tibetan Plateau during Recent Decades. International Journal of Climatology, 20, 1729-1742.

http://dx.doi.org/10.1002/1097-0088(20001130)20:14<1729::AID-JOC556>3.0.CO;2-Y

[75] Liu, K.B., Yao, Z. and Thompson, L.G. (1998) A Pollen Record of Holocene Climatic Changes from the Dunde Ice Cap, Qinghai-Tibetan Plateau. Geology, 26, 135-138. http://dx.doi.org/10.1130/0091-7613(1998)026<0135:APROHC >2.3.CO;2

[76] Miehe, G., Kaiser, K., Co, S., Xinquan, Z. and Jianquan, L. (2008) Geo-Ecological Transect Studies in Northeast Tibet (Qinghai, China) Reveal Human-Made Mid-Holocene Environmental Changes in the Upper Yellow River Catchment Changing Forest to Grassland. Erdkunde, 62, 187-199. http://dx.doi.org/10.3112/erdkunde.2008.03.01

[77] Schlütz, F. and Lehmkuhl, F. (2009) Holocene Climatic Change and the Nomadic Anthropocene in Eastern Tibet: Palynological and Geomorphological Results from the Nianbaoyeze Mountains. Quaternary Science Reviews, 28, 1449-1471.

http://dx.doi.org/10.1016/j.quascirev.2009.01.009 


\section{List of Abbreviations}

$4.2 \mathrm{ka} \quad 4200$ Years Ago

BCE Before Common Era

CCM0 Community Climate Model 0 of the National Center for Atmospheric Research

E Evaporation

ENSO El Niño-Southern Oscillation

HCO Holocene Climatic Optimum

ITCZ Intertropical Convergence Zone

MLW Mid-Latitudes Westerlies

$\mathrm{P} \quad$ Precipitation

$\mathrm{P} / \mathrm{E}$ ratio Precipitation/Evaporation Ratio

SST Sea Surface Temperature

Submit or recommend next manuscript to SCIRP and we will provide best service for you:

Accepting pre-submission inquiries through Email, Facebook, LinkedIn, Twitter, etc.

A wide selection of journals (inclusive of 9 subjects, more than 200 journals)

Providing 24-hour high-quality service

User-friendly online submission system

Fair and swift peer-review system

Efficient typesetting and proofreading procedure

Display of the result of downloads and visits, as well as the number of cited articles

Maximum dissemination of your research work

Submit your manuscript at: http://papersubmission.scirp.org/

Or contact oje@scirp.org 